\title{
Ecological studies on the aquatic macro-invertebrate population dynamics of the snow-fed Kali River in Uttarakhand, India
}

\author{
Rakesh Verma $^{1^{*}} \cdot$ Priyanka Sharma $^{1} \bullet$ Lata Upadhyay $^{1}$ \\ ${ }^{1}$ Department of Zoology, LSM Govt. PG College Pithoragarh, Uttarakhand (262501), India \\ *Corresponding author: rv.pith@gmail.com
}

Received: 25.8.2021; Revised: 16.12.2021; Accepted: 27.12.2021

(C) Society for Himalayan Action Research and Development

\begin{abstract}
Freshwater macro-invertebrates are the bottom dwelling organisms. Their presence, distribution and diversity is affected by many eco-biological factors. The aim of this study was to assess the factors that impact upon the population dynamics of macro- invertebrates, while correlating the relationship between various physio-chemical parameters and macro-invertebrates from the Kali River, Pithoragarh (Uttarakhand). The samples were collected using a quartet square in the sampling area of one square feet of the stream bed, which was then, after placing in $70 \%$ alcohol, taken to the laboratory for identification and enumeration. A total of 24 genera and 28 species were found during the study, which belongs to 3 phylum, 5 classes, 10 order and 20 families. A total of eight physiochemical parameters were studied on a monthly basis round the year. The ecological impact was measured by establishing the correlation between recorded physio-chemical parameters and invertebrates' diversity, in which water temperature, air temperature, velocity, and conductivity showed a negative correlation while $\mathrm{pH}, \mathrm{DO}$, total alkalinity, and total hardness showed a positive correlation. Various alpha diversity indices were estimated with the help of PAST software which indicated diverse macro-invertebrate communities in the Kali River in District Pithoragarh.
\end{abstract}

Key words: Macro-invertebrates, Population dynamics, Biodiversity, Kali River

\section{Introduction}

Benthic macro-invertebrates in an aquatic ecosystem are bottom dwelling organism mostly used as reliable bio-indicators. These are microscopic to macroscopic ranges in size between $<500 \mu \mathrm{m}$ to many centimeters, which in turn become food for fishes (Bae et al., 2005, Beauger et al., 2006). Macro-invertebrates are mainly studied for the assessment of ecological integrity as they ensure a wide range of sensitivities to change in both water quality and habitats with low mobility (Feio et al., 2007). They're known as benthic macro-invertebrates, due to their tendency to inhabit bottoms (Bhandarkar et al., 2020). Macro-invertebrates are an integral part of the aquatic ecosystems, acting as a link between primary producers, decomposers, and higher trophic levels, involved in energy pathways and nutrient cycles (Gordon, 2000), and in this way, they serve as promoting indicators for the development of the health of the aquatic ecosystem (Nazarova et al., 2004). They also have the ability to clean rivers, as they are comprised of several types of feeding groups. Thus, their abundance, diversity, biomass, and species composition could be a bio-monitor for environmental changes (ElShabrawy and Fishar, 2009).

The health and condition of the aquatic ecosystem can be depicted by the study of the structure of the macro-invertebrates' community (Buss et al., 2004, Dar et al., 2010). Similarly, 
the abundance, distribution, and survival of macro-invertebrates also depend on the characteristics of their aquatic environment (Gallardo et al., 2014; Brooks \& Haeusler, 2016). Depending on the diverse taxa and their relative abundance, macro- invertebrates indicates the pollution status of rivers. Species diversity indices plays an important role in analyzing the community structure of this heterogeneous collection of organisms inhabiting freshwater, and for evaluating the health of the aquatic ecosystem (Beena et al., 2020, Dani et al.,2019). Several studies have been conducted in recent years on the extensive freshwater macro-invertebrates and the pattern of species assemblages related to environmental variables using multivariate techniques in various parts of the globe (Langdon et. al., 2006; Pathani and Upadhyay, 2006; Zettler and Darius, 2007). However, the ecology of the aquatic macro-invertebrates of the river 'Kali' has received less attention. The main objective of this study was to study the macrozoobenthic species composition and their interaction with environmental conditions.

\section{Material and Methods}

The study was conducted on the rain-fed river Kali $\left(29^{\circ} 24^{\prime} 09\right.$ "N latitude and 80¹5'17 "E longitude) in the Kumaun region of Uttarakhand, which rises from the Namik Glacier and is the main tributary of the Ganges River.

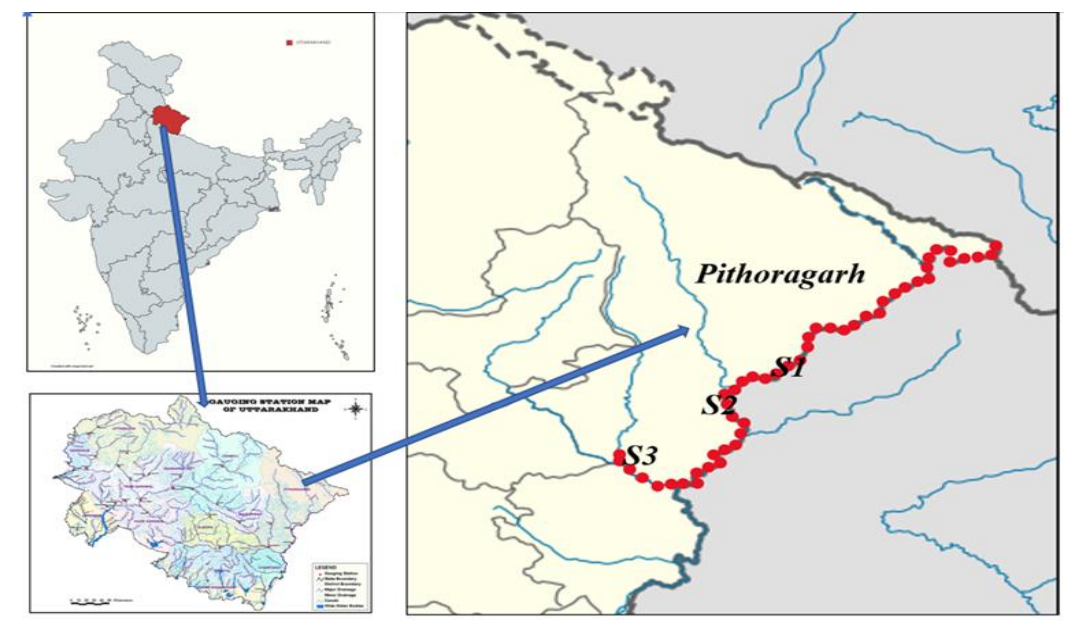

Figure1: Map showing various study sites in Kumaun Himalayan region

\section{Physio-chemical parameters}

Various physio-chemical parameters (water temperature, $\mathrm{pH}$, total alkalinity, total hardness, and dissolved oxygen) of the stream were analyzed using APHA (2012) which were correlated with the density and diversity of the macro-invertebrates with the help of established statistical techniques. The conductivity was measured on the spot with the help of an $\mathrm{HI}$ 8033 conductivity meter and expressed as $\mu \mathrm{S} / \mathrm{cm}$. The speed of the water current was 
measured by the surface float method and calculated in meters/second.

\section{Macro-invertebrate sampling and analysis}

Stony bed macro-invertebrates were collected quantitatively using a quartet square in a sampling area of one square feet of the stream bed. On the downstream side of the sampling area, floating net was placed to collect moving samples or organisms. The quadrate was set,

then collection was done at a depth of about 15 $\mathrm{cm}$ and immediately placed in $70 \%$ alcohol. Then they were taken to the lab for identification and enumeration. The macro-invertebrates were identified and classified up to the lowest possible practical taxonomic level (Oscoz and Galicia, 2011, Feldman, et. al., 2006). After taxonomy, various alpha diversity indices were calculated by using PAST software (Hammer et al., 2001).

\section{Results and Discussion}

The population dynamics of macro-invertebrates in the river was mainly studied for their density and diversity using standard indices. Influential ecological parameters were analysed to correlate with benthic density and diversity. The Phylum Arthropoda with one class had six orders. The Ephemeroptera was dominating order with seven families, eleven genera, and twelve species, the Diptera order was second largest with three families, three genera, and six species. The Odonata Order had three families, three genera, and three species. The three orders, Plecoptera, Coleoptera, and Trichoptera, had one family, one genus, and one species each. Annilida was the second largest phylum, with three classes (Clitellata, Oligochaeta, and Polychaete), three orders (Rhynchobdellida, Gnathobdellida, and Pogonophara), three genera, and three species. Phylum Platyhelminthes with a single Class Turbellaria, including a single order Tricladida, with a single Family Dugesiidae, with a single Genus Dugesia was found.

A total of twenty-four genera and twenty-eight species were classified and recorded (Table 1). The highest number of individuals per square feet was recorded in the month of July with a value of 234 and the lowest in September at 98 sqft. (Table 2). The value of dominance was highest in the month of July and lowest in the month of August with the value of 0.05627 and 0.041 respectively. Simpson value was found highest in June and lowest in July with value of 0.9577 and 0.9437 . Shannon index value was found highest in June and lowest in September with the value of 3.234 and 3.003, and the evenness value was found highest in the month of May and lowest in the month of July with the value of 0.966 and 0.8359 respectively (Table 2).

During the study, the average maximum and minimum values of water temperature were $23.9^{\circ} \mathrm{C}$ and $11.8^{\circ} \mathrm{C}$ in September and February 
respectively (Table 3). The relationship between water temperature and macro-invertebrate showed a negative correlation $[\mathrm{y}=9.246 \ln (\mathrm{x})$ 23.79, $\left.\mathrm{R}^{2}=0.302\right]$ (Table 4). The average maximum and minimum values of water temperature were $23.9^{\circ} \mathrm{C}$ and $11.8^{\circ} \mathrm{C}$ in September and February respectively (Table 3). The relationship between water temperature and macro-invertebrate showed a negative correlation $\left[\mathrm{y}=7.357 \ln (\mathrm{x})-17.86, \mathrm{R}^{2}=0.223\right]$

(Table 4). The $\mathrm{pH}$ values ranged between 9.4 in
March and 7.9 in November respectively (Table 3). The relationship between $\mathrm{pH}$ and macroinvertebrate was observed to have a positive correlation $\left[\mathrm{y}=0.255 \ln (\mathrm{x})+7.538, \mathrm{R}^{2}=0.022\right]$ (Table 4). The dissolved oxygen fluctuates between $10.6 \mathrm{mg} / \mathrm{l}$ in January and $8.5 \mathrm{mg} / \mathrm{l}$ in May (Table 3). In the present work, a positive correlation was observed between macroinvertebrate and dissolved oxygen $[\mathrm{y}=-0.57 \mathrm{ln}$ $\left.(\mathrm{x})+12.34, \mathrm{R}^{2}=0.068\right]$ (Table 4).

Table1. List of macro-invertebrate found from sampling area of Kumaun Himalayan region

\begin{tabular}{|c|c|c|c|c|c|c|}
\hline PHYLUM & CLASS & ORDER & FAMILY & GENUS & SPECIES & COMMON NAME \\
\hline \multirow{24}{*}{ 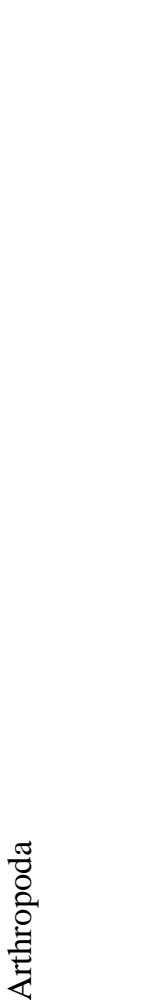 } & \multirow{24}{*}{$\begin{array}{l}\stackrel{\Xi}{U} \\
\vdots \\
\Xi\end{array}$} & \multirow{12}{*}{$\begin{array}{l}\text { Ephemeropter } \\
\mathrm{a}\end{array}$} & \multirow{4}{*}{ Baetidae } & Baetis & buceratus & Small minnow mayflies \\
\hline & & & & & vernus & Small mayflies \\
\hline & & & & Platybaetis & arunachalae & - \\
\hline & & & & Nigrobaetis & paramakalyani & Nigrobaetis vuatazi \\
\hline & & & \multirow[t]{2}{*}{ Ephemerellidae } & Ephemerella & dorothea & Spiny CrawlerMayflies \\
\hline & & & & Attenella & margarita & Spiny CrawlerMayflies \\
\hline & & & Isonychidae & Isonychia & japonica & brush-legged mayfly \\
\hline & & & Caenidae & Caenis & vanuatensis & Square-gilledMayflies \\
\hline & & & Leptopjhlebiidae & Neoleptophlebia & mollis & Prong-gilled Mayflies \\
\hline & & & \multirow[t]{2}{*}{ Heptageniidae } & Rhithrogena & hageni & Western black quill \\
\hline & & & & Stenacron & interpunctatum & Flat-headed mayflies \\
\hline & & & Potamanthidae & Anthopotamus & myops & Hackle-gills \\
\hline & & \multirow[t]{6}{*}{ Diptera } & \multirow[t]{2}{*}{ Simuliidae } & \multirow[t]{2}{*}{ Simulium } & aestivum & Black flies \\
\hline & & & & & anatinum & Coloured black flies \\
\hline & & & \multirow[t]{2}{*}{ Tipulidae } & \multirow[t]{2}{*}{ Tipula } & accurata & Large Crane Flies \\
\hline & & & & & appendiculata & Cranefly larvae \\
\hline & & & \multirow[b]{2}{*}{ Chironomidae } & \multirow[b]{2}{*}{ Chironomus } & salinarius & Non-Bitting Midges \\
\hline & & & & & plumosus & Buzzer midge \\
\hline & & Plecoptera & Dytiscidae & Neptosternus & gutticollis & Diving beetle \\
\hline & & Coleoptera & Psephenidae & Psephenus & herricki & Water Pennies \\
\hline & & \multirow[t]{3}{*}{ Odonata } & Calopterygidae & Echo & hetaerina & Rubyspots \\
\hline & & & Aeshnidae & Anax & boyeria & Dragonfly \\
\hline & & & Cordullidae & Cordulegaster & epitheca & Baskettails \\
\hline & & Trichoptera & Hydropsychidae & Hydropsyche & phalerata & - \\
\hline \multirow[t]{3}{*}{ Annelida } & Clitellata & $\begin{array}{l}\text { Rhynchobdelli } \\
\text { da }\end{array}$ & Glossophonidae & Glossiphonia & heteroclita & Small snail leech \\
\hline & Oligochaeta & $\begin{array}{l}\text { Gnathobdellid } \\
\text { a }\end{array}$ & Hirudinidae & Hirudo & medicinalis & Freshwater leech \\
\hline & Polychaete & Pogonophara & Siboglinidae & Sclerolinum & pogonopharan & Beard worms \\
\hline $\begin{array}{l}\text { Platyhel } \\
\text { minthes }\end{array}$ & Turbellaria & Tricladida & Dugesiidae & Dugesia & sagitta & Flatworms \\
\hline
\end{tabular}


Table 2: Alpha diversity indices of macroinvertebrates calculated by PAST statistical software

\begin{tabular}{ccccccc}
\hline Month & Taxa_S & Individuals & Dominance_D & $\begin{array}{c}\text { Simpson_1- } \\
\text { D }\end{array}$ & $\begin{array}{c}\text { Shannon_ } \\
\text { H }\end{array}$ & $\begin{array}{c}\text { Evenness_e } \\
\text { ^H/S }\end{array}$ \\
\hline June & 27 & 220 & 0.04226 & 0.9577 & 3.234 & 0.94 \\
July & 25 & 234 & 0.05627 & 0.9437 & 3.04 & 0.8359 \\
August & 27 & 187 & 0.041 & 0.959 & 3.233 & 0.9402 \\
September & 22 & 98 & 0.05344 & 0.9466 & 3.003 & 0.9157 \\
October & 23 & 113 & 0.04883 & 0.9512 & 3.085 & 0.9503 \\
November & 24 & 175 & 0.04808 & 0.9519 & 3.103 & 0.9274 \\
December & 24 & 120 & 0.04804 & 0.952 & 3.075 & 0.902 \\
January & 24 & 130 & 0.04436 & 0.9556 & 3.123 & 0.9469 \\
February & 27 & 144 & 0.04244 & 0.9576 & 3.223 & 0.9301 \\
March & 24 & 97 & 0.04875 & 0.9512 & 3.104 & 0.9282 \\
April & 27 & 145 & 0.04272 & 0.9573 & 3.219 & 0.926 \\
May & 25 & 200 & 0.04327 & 0.9567 & 3.184 & 0.966 \\
\hline
\end{tabular}

Table 3. Average annual variations in the pool data of Individuals/sqft and physio-chemical parameters from sampling area

\begin{tabular}{lllllllll}
\hline Month & $\begin{array}{l}\text { pool data } \\
\text { of } \\
\text { Individu } \\
\text { als/sqft }\end{array}$ & $\begin{array}{l}\text { Water } \\
\text { Temp } \\
\left({ }^{\mathbf{0}} \mathbf{C}\right)\end{array}$ & $\mathbf{p H}$ & $\begin{array}{l}\text { D.O. } \\
(\mathbf{m g} / \mathbf{l})\end{array}$ & $\begin{array}{l}\text { Total } \\
\text { Alkali } \\
\text { nity } \\
(\mathbf{m g} / \mathbf{l})\end{array}$ & $\begin{array}{l}\text { Total } \\
\text { Hardness } \\
(\mathbf{m g} / \mathbf{l})\end{array}$ & $\begin{array}{l}\text { Velocity } \\
(\mathbf{m} / \mathbf{s})\end{array}$ & $\begin{array}{l}\text { Conductivity } \\
(\boldsymbol{\mu S} / \mathbf{c m})\end{array}$ \\
\hline Jun & 220 & 23.5 & 8.6 & 9.6 & 70.1 & 89.7 & 0.78 & 140.5 \\
Jul & $\mathbf{2 3 4}$ & 24.4 & 9.1 & 9.3 & $\mathbf{6 7 . 8}$ & $\mathbf{8 2 . 5}$ & 0.87 & $\mathbf{1 4 0 . 8}$ \\
Aug & 187 & 23.6 & 9.3 & 8.7 & 70.5 & 84.4 & $\mathbf{0 . 8 1}$ & 90.6 \\
Sep & $\mathbf{9 8}$ & $\mathbf{2 3 . 9}$ & 8.4 & 9.5 & 70.0 & 86.3 & 0.77 & $\mathbf{9 3 . 5}$ \\
Oct & 113 & 19.5 & 8.1 & 8.9 & 71.9 & 88.6 & 0.53 & 98.5 \\
Nov & 175 & 17.4 & $\mathbf{7 . 9}$ & 9.6 & 75.2 & 90.2 & 0.43 & 101.2 \\
Dec & 120 & 13.8 & 8.4 & 10.4 & 77.5 & 90.2 & 0.39 & 101.3 \\
Jan & 130 & 12.3 & 8.9 & $\mathbf{1 0 . 6}$ & 79.5 & 95.3 & $\mathbf{0 . 3 0}$ & 110.2 \\
Feb & 144 & $\mathbf{1 1 . 8}$ & 9.2 & 10.3 & $\mathbf{8 4 . 1}$ & 98.4 & 0.33 & 117.7 \\
Mar & 97 & 14.8 & $\mathbf{9 . 4}$ & 9.2 & 81.2 & 100.3 & 0.35 & 124.3 \\
Apr & 145 & 20.9 & 9.3 & 9.3 & 75.3 & $\mathbf{1 0 0 . 4}$ & 0.43 & 130.6 \\
May & 200 & 21.4 & 9.1 & $\mathbf{8 . 5}$ & 72.8 & 96.4 & 0.40 & 135.5 \\
\hline
\end{tabular}

Table 4. Annual data statistical modeling of macro-invertebrate

\begin{tabular}{ccccc}
\hline 1. & macro-invertebrate & $\mathrm{y}=7.357 \ln (\mathrm{x})-17.86$ & Water Temp & $\mathrm{R}^{2}=0.223$ \\
2. & macro-invertebrate & $\mathrm{y}=0.255 \ln (\mathrm{x})+7.538$ & $\mathbf{p H}$ & $\mathrm{R}^{2}=0.022$ \\
3. & macro-invertebrate & $\mathrm{y}=-0.57 \ln (\mathrm{x})+12.34$ & $\mathbf{D . 0 .}$ & $\mathrm{R}^{2}=0.068$ \\
4. & macro-invertebrate & $\mathrm{y}=-7.80 \ln (\mathrm{x})+113.6$ & Total Alkalinity & $\mathrm{R}^{2}=0.220$ \\
5. & macro-invertebrate & $\mathrm{y}=-6.49 \ln (\mathrm{x})+124.3$ & Total Hardness & $\mathrm{R}^{2}=0.104$ \\
6. & macro-invertebrate & $\mathrm{y}=0.301 \ln (\mathrm{x})-0.973$ & Velocity & $\mathrm{R}^{2}=0.187$ \\
7. & macro-invertebrate & $\mathrm{y}=31.80 \ln (\mathrm{x})-43.7$ & Conductivity & $\mathrm{R}^{2}=0.272$ \\
\hline
\end{tabular}


In the present investigation on river Kali a total of 24 genera, and 28 species of aquatic macroinvertebrates belonging to 3 phylum, 5 classes, 10 order and 20 families were found (Table 1). The Ephemeroptera was the dominant order, followed by Diptera, Plecoptera, Coleoptera, Odonata, Trichoptera and Tricladida which suggested that the Kali River has a good macroinvertebrate distributional pattern. Similarly, Nautiyal, (2006) found 30 macro-invertebrate's taxa in the Ganga River, with Ephemeroptera dominating and Diptera, Tricoptera, and Plecoptera were following. Sehgal, (1990) also found 57 genera of invertebrates in 11 rivers. Mohan, (2005) observed 50 genera of invertebrates from the Sherkhad stream in Himachal Pradesh.

Various diversity indices were showing annual variation throughout the study period which may be due to climatic conditions and may be due to the region's increased influence of human activities (Table 2). Alpha diversity indices are one of the best indicators of species richness and an index to evaluate the population density of aquatic macro-invertebrates (Balodi, 2000). The highest number of individuals per square feet was recorded in the month of July at 234 and the lowest in September at $98 \mathrm{~m} / \mathrm{sq}$. (Table 2), respectively. The high value of diversity indices revealed that the river's physical and chemical features were stable in that particular month. Thus, the high diversity of benthic populations in the streams studied here can be attributed to favourable environmental conditions. Similar results regarding the population diversity of aquatic macroinvertebrates have been found by (Langdon et. al., 2006, Pathani and Upadhyay, 2006, and Jones et al. 2012), in their study.

Water sample analysis reveals seasonal variations in the different physio-chemical parameters with their different ranges, like the average water temperature range of $15-20^{\circ} \mathrm{C}, \mathrm{pH}$ range 9.4-7.9, DO range 10.6-8.5 mg. $\mathrm{l}^{-1}$, alkalinity range $67.8-84.1 \mathrm{mg} .1^{-1}$, hardness range 82.5-100.4 mg. $\mathrm{l}^{-1}$, velocity and conductivity

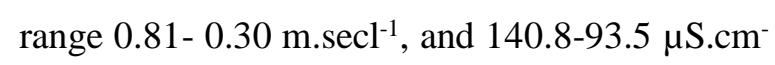
1 respectively. A similar range of physiochemical parameters for the river have also been recorded by many researchers (Gupta et al., 2017, Maurya, 2012, Kumar and Bahadur, 2009), respectively. During this study, a negative correlation was shown between water temperature, velocity, and conductivity with the macro-invertebrate population. On the other hand, the correlation with macro-invertebrates was found positive with $\mathrm{pH}, \mathrm{DO}$, total alkalinity, and total hardness. The correlation established between biotic and abiotic factors showed that various parameters affect population dynamics (Dar et al., 2010, Gallardo et al. 2014, Brooks and Haeusler, 2016).

\section{Acknowledgements}

The authors are grateful to the department of Zoology, L.S.M. Government Post Graduate 
College, Pithoragarh for technical support and laboratory facilities.

\section{References}

APHA, (2012). Standard Methods for the Examination of Water and Wastewater. APHA, AWWA, WPCF, 22 $2^{\text {th }}$ edition, New York.

Bae Y J, Kil H K, Bae K S (2005). Benthic macroinvertebrates for uses in stream biomonitoring and restoration. KSCE Journal of Civil Engineering, 9(1), 55- 63.

Balodi V P (2000). Ecological studies on $t$ macrozoobenthic communities of the Nay river system correlated with its fish environment (Doctoral dissertation, D. Phil. Thesis, HNB Garhw University, Srinagar Garhwal).

Beauger A, Lair N, Reyes-Marchant P, Peiry J L (2006). The distribution of macroinvertebrate assemblages in a reach of the River Allier (France), in relation to riverbed characteristics. Hydrobiologia, 571(1), 63-76.

Beena S K, Sreejai R, Athira U, Dani Benchamin, Jensy Roshan . F, Sujitha .S. (2020). Systematics of benthic fauna in achenkovil river- a segmental approach. Climate Change Impacts and Human Interventions on Biodiversity and Environment. Daya Publishing House Astral International. Pvt. Ltd. New
Delhi.110002. ISBN. No:978-93-89719-383.

Bhandarkar Sudhir, Paliwal Gopal (2020). Short Notes on Types Of Benthic Invertebrates. Bhumi Publishing, India. Limnology; 2532.

Brooks A J,, Haeusler T (2016). Invertebrate responses to flow: trait-velocity relationships during low and moderate flows. Hydrobiologia, 773(1), 23-34.

Buss D F, Baptista D F, Nessimian J L., Egler M (2004). Substrate specificity, environmental degradation and disturbance structuring macroinvertebrate assemblages in neotropical streams. Hydrobiologia, 518(1), 179-188.

Dani B, Sreejai R, Beena S K (2019). Water quality assessment in Kallada River using Ephemeroptera, Plecoptera and Trichoptera. Proceedings of the Thirteenth All India Conference of KAAS (pp 10-13). ISBN No. 978-93-81658-26-0. Zoology.

Dar IY, Bhat G A, Dar Z A (2010). Ecological distribution of Macrozoobenthos in Hokera wetland of JK, India. Journal of Toxicology and Environmental Health Sciences, 2(5), 63-72.

El-Shabrawy G M, Fishar M R (2009). The Nile Benthos. In The Nile (563-583). Springer, Dordrecht. 
Feio, Maria \& Almeida, Salomé \& Craveiro, Sandra \& Calado, António. (2007). Diatoms and macroinvertebrates provide consistent and complementary information on environmental quality. Fundamental and Applied Limnology / Archiv für Hydrobiologie. 169 247-258. 10.1127/1863-9135/2007/0169-0247.

Feldman, D. (2006). Interpretation of New Macroinvertebrate Models by WQPB. Draft Report. Montana Department of Environmental Quality, Planning Prevention and Assistance Division, Water Quality Planning Bureau, Water Quality Standards Section.1520 E. 6th Avenue, Helena, MT 59620. 14.

Gallardo, B., Dolédec, S., Paillex, A., Arscott, D. B., Sheldon, F., Zilli, F., ... \& Comín, F. A. (2014). Response of benthic macroinvertebrates to gradients in hydrological connectivity: a comparison of temperate, subtropical, Mediterranean and semiarid river floodplains. Freshwater Biology, 59(3), 630-648.

Gordon, C. (2000). Hypersaline lagoons as conservation habitats: macro-invertebrates at Muni Lagoon, Ghana. Biodiversity \& Conservation, 9(4), 465-478.

Gupta N, Pandey P, Hussain J (2017). Effect of physicochemical and biological parameters on the quality of river water of Narmada,
Madhya Pradesh, India. Water Science, 31(1), 11-23.

Hammer, Ø., Harper, D. A., \& Ryan, P. D. (2001). PAST: Paleontological statistics software package for education and data analysis. Palaeontologia electronica, 4(1), 9

Jones, J. I., Murphy, J. F., Collins, A. L., Sear, D. A., Naden, P. S., \& Armitage, P. D. (2012). The impact of fine sediment on macro-invertebrates. River research and applications, 28(8), 1055-1071.

Kumar A, Bahadur Y (2009). Physico-Chemical Studies on the Pollution Potential of River Kosi at Rampur (India). World Journal of Agricultural Sciences, 5(1), 1-4.

Langdon P G, Ruiz Z O E, Brodersen K P, Foster I D (2006). Assessing lake eutrophication using chironomids: understanding the nature of community response in different lake types. Freshwater biology, 51(3), 562-577.

Maurya, P. K., Zaidi, J., \& Pal, A. (2012). Physico-chemical properties of Barua Sagar lake water, Jhansi, Uttar Pradesh India. Elixir Pollution, 42, 6355.

Mohan M (2005). Benthic macro-biota in Gaula River-Kumaon Himalaya. Journal of the Indian Fisheries Association, 32, 49-67.

Nautiyal P, Semwal V P (2006). Benthic macroinvertebrate community in the 
mountain streams: longitudinal patterns of distribution in west Himalaya (Gangetic drainage-Mandakini basin). J Mt Res, 1, $39-49$.

Nazarova L B, Semenov V F, Sabirov R M, Efimov, I. Y. (2004). The state of benthic communities and water quality evaluation in the Cheboksary Reservoir. Water Resources, 31(3), 316-322.

Oscoz, J., Galicia, D., \& Miranda, R. (Eds.). (2011). Identification guide of freshwater macroinvertebrates of Spain. Springer Science \& Business Media, 176.

Pathani S S, Upadhyay K K (2006). An inventory on zooplankton, zoo benthos and fish fauna in the river Ram Ganga (W) of Uttaranchal, India. ENVIS Bulletin, 14(2), $37-46$.

Sehgal K L (1990): Report on the impact of construction and completion of Beas-Sutlej Link (BSL). Project on limnology and fisheries of river Beas. CIFRINRCICWFl; Publication.

Zettler M L, Daunys D (2007). Long-term macrozoobenthos changes in a shallow boreal lagoon: comparison of a recent biodiversity inventory with historical data. Limnologica, 37(2), 170-185. 